\title{
The effect of local-based feed ration on the production and quality of duck eggs in Tanjungpinang, Riau Islands
}

\author{
Salfina Nurdin Ahmad ${ }^{1}$, Yeni Yusriani $^{2}$, Apriyani Nur Sariffudin ${ }^{1}$, Khoiru Rizqy Rambe ${ }^{1}$, \\ Annisa Dhienar Alifia ${ }^{1}$, Irma Oktavia $^{1}$, and Sugeng Widodo ${ }^{1}$ \\ ${ }^{1}$ Riau Islands Assessment Institute for Agricultural Technology, Ministry of Agriculture, \\ Tanjungpinang, 29124, Indonesia \\ ${ }^{2}$ Aceh Assessment Institute for Agricultural Technology, Ministry of Agriculture, Banda Aceh, \\ 23125, Indonesia
}

\begin{abstract}
The aim of the study was to determine effect of local feed on the production and quality of duck eggs in Tanjungpinang, Riau Islands. This study was conducted in Juli 2020 in Dompak Village, Tanjungpinang City. The material of research were Mojosari duck ages 38-48 weeks and local feed (feed A, B and C). This study used a non-experimental design using a survey method. Sampling using purposive sampling method. The parameter measured were egg weight, shell weight, shell thickness, yolk color and egg production. The data obtained were then compared to the average using the Mann-Whitney test. The results showed that the ration A treatment was not significantly different from ration $B(P>0,05)$ but both were significantly different from ration $\mathrm{C}(\mathrm{P}<0,05)$ in the physical quality parameters of eggs, while the parameters of egg production of the 3 treatments local feed had no significant effect $(\mathrm{P}>0,05)$. The highest duck egg production was obtained from ration $\mathrm{B}$, which was 80 eggs per day. The conclusion of this study is that the treatment of local feed-based rations can affect the physical quality of Mojosari duck egg.
\end{abstract}

\section{Introduction}

Poultry is a livestock commodity that can be categorized into meat-producing and egglaying ones [1]. Apart from chickens, duck's meat and egg contribute significantly to provide highly nutritional food [2]. Local ducks are classified as the Indian Runner duck breed and are also one of Indonesia's germplasm. These ducks are known as egg producers. Varieties of the Indian runner ducks spread throughout Indonesia are named according to the regions they originated, such as Tegal ducks, Magelang ducks, Mojosari ducks, and Alabio ducks. Each type of duck has different productivity [3].

The type of duck widely cultivated in Tanjungpinang City is the Mojosari duck. Female Mojosari ducks are developed as egg layers and the male ones as meat-producer [2]. Nutritious feed application has been proven to improve Mojosari duck productivity [4].

\footnotetext{
* Corresponding author: salfina.bptp@gmail.com
} 
However, feed with good quality and nutrient content is usually high-priced. Local feed utilization can be done as an alternative to overcome this problem. Environmental conditions strongly influence local feed availability. The difference in environmental conditions of each region results in different natural resources.

Fisheries waste or byproducts can be utilized as local feed [5]. Local sea products from Riau Islands are abundant, with 455,779.9 ha of sea area suitable for marine culture [6]. Plantation waste used as local feed is sago waste and coconut waste. Sago waste comes from the sago processing or milling place, while coconut waste is obtained from the market located in the city of Tanjungpinang. Fishery waste used is marine fish waste and shrimp head waste.

In addition, farm management is an important aspect of duck meat and egg farming [7]. Most of the duck rearing in the city of Tanjungpinang uses a semi-intensive system. The difference in the maintenance system lies in the housing perspective and fulfilling the nutrient needs of the ducks. Feed is the source of the nutrient. Different types of feed can cause differences in feed intake, which affect the quality and production of duck eggs. Therefore, this study aims to determine the effect of local feed-based rations on the physical quality and egg production of Mojosari ducks in Tanjungpinang city.

\section{Materials and methods}

\subsection{Location}

The field research was carried out in Dompak Village, Tanjungpinang City in July 2020 by involving local farmer groups while laboratory research was carried out at the Indonesian Research Institute for Animal Production (IRIAP) Laboratory, Bogor, Indonesia, and at Riau Islands Assessment Institute for Agricultural Technology, Tanjungpinang, Indonesia.

\subsection{Materials}

The research materials used were Mojosari ducks aged 38-48 weeks. There are 3 types of rations made from local feed (rations $\mathrm{A}, \mathrm{B}$ and $\mathrm{C}$ ) or feed commonly given by local breeders. The tools used in the study were the cage, the feed, the drinking area, the digital scale, the calipers, the screw micrometer, and the yolk color fan.

\subsection{Methods}

The research was conducted in 3 stages: preparation stage, research implementation, and data analysis.

This stage includes making questionnaires and taking feed samples. The samples are to be tested at the Laboratory of the Indonesian Research Institute for Animal Production (IRIAP) in Ciawi, Bogor.

Direct interviews to breeders were conducted using a questionnaire. Observations were also made directly on the parameters, which included egg weight, eggshell weight, shell thickness, egg yolk score, and egg production.

(a) Egg weight

Egg weight is measured by weighing eggs using digital scales in grams.

(b) Shell weight and thickness. Shell weight is measured by weighing the eggshell using a digital scale in grams, while the thickness of the shell is measured using a screw micrometer with units in $\mathrm{mm}$.

(c) Yolk color score. Egg yolk color was measured using the Egg Yolk Color Fan. 
(d) Egg production. Calculated based on the number of eggs produced per day divided by the number of ducks multiplied by $100 \%$.

The research design used was non-experimental research using a survey method. The survey was conducted on all farmers from the Maju Jaya Farmer Group. Sampling using purposive sampling method. Samples from the Maju Jaya livestock group were divided into 3 feed treatments. Feed A: 30\% bran $+30 \%$ corn $+20 \%$ shrimp flour $+5 \%$ fermented sago $+15 \%$ concentrate. Feed B: $70 \%$ feed A $+30 \%$ conventional feed. Feed C: $60 \%$ feed A + $30 \%$ conventional feed $+10 \%$ bran.

The data obtained were then compared to the average using a non-parametric statistical test, namely the Mann-Whitney test. Data testing was performed using data processing software.

\section{Results and discussion}

\subsection{General condition of Maju Jaya livestock farmer group}

The Maju Jaya farmer group is the center for duck farming in the Riau Islands province, especially the city of Tanjungpinang. The location of the Maju Jaya livestock herd is approximately $500 \mathrm{~m}$ near community settlements and $4 \mathrm{~km}$ from the market. This location is in accordance with the requirements determined by the Ministry of Agriculture 2007 which states that the appropriate location for duck farms is at least $250 \mathrm{~m}$ from residential areas. The location of the farm should be in accordance with the location determined by the local government and close to the market and production center for livestock commodities [8].

There are 12 members of Maju Jaya group with ages ranging from 30-60 years, thus classified them as productive age class. Productive age affects the ability of breeders to work, because their productivity will decrease as they are getting older. The population of productive age in Indonesia ranges from 15 - 64 years [9]. On productive age the possibility of increasing productivity and income is very high because farmers are more optimal in managing their farms [10]. The increasing age can maintain emotional stability and can reduce physical abilities [11].

Farming laying duck is considerably new experience for Maju Jaya Farmer Group, ranging from 1-3 years. Even so, the Maju Jaya livestock group is very creative because it has a mini factory and has a fairly wide network. The experience of breeders is related to breeders' knowledge and breeders' skills in doing work. The experience of breeders in farming is related to critical and careful actions in carrying out work [10]. The increasing farmer experience can improve farmer skills and knowledge [11].

Most of the cages used for laying ducks are still covered with dry grass with the aim of preventing the eggs from breaking easily. The most commonly used construction materials for duck cages are wood and bamboo because they are cheap and durable [12]. Maju Jaya livestock group use semi intensive duck raising system. The cattle are herded on the swamp land around the pen in the morning, then the ducks are put back in the pen in the afternoon. Feeding is done in the afternoon. The feed used in raising ducks comes from around the site. The ownership of ducks in the Maju Jaya group varies from 40-600 head. The maximum population of ducks was 3 breeders, namely breeder A around 600 heads, breeder $\mathrm{B}$ with 300 heads, and breeder $\mathrm{C}$ around 250 heads.

The three feed rations cost are different. The cost of feed C is around IDR740 per head. This is the lowest price compared to the other two rations. Feed B costs around IDR770 per head, and feed A around IDR900 per head. Thus, the most affordable feed is the Feed C. However, this study showed that feed $\mathrm{C}$ resulted in smaller egg than feed $\mathrm{A}$ and $\mathrm{B}$, 
indicating that this feed is not the best at its value. Meanwhile, feed B egg quality parameters results are not significantly different than feed A treatment. Therefore, feed B which is cheaper than feed A might be the better option for the farmers to get best result at more affordable feed ration price.

\subsection{Feed nutritional content}

The feed nutritional content can be seen in Table 1. According to Indonesian National Standard (SNI), the quality requirements for laying duck feed content are metabolism energy at $\min 2,650 \mathrm{kcal}$, crude protein (PK) at min $15 \%$, crude fiber (SK) at maximum $8 \%$, crude fat (LK) at maximum $7 \%$, calcium content at $3.0-4.0 \%$, and $\mathrm{P}$ total at $0.6-1.0 \%$ [13].

The three feed treatments contain more than enough metabolism energy value with all of them above the minimum requirements $(2,951-3,120 \mathrm{kcal})$. The crude protein, crude fat, crude fiber, and phosphor content of the three feeds met the SNI requirements. However, the calcium contents of the three feeds are slightly above the standard. All of them are above $4 \%$, with feed $\mathrm{A}$ at the highest $(6.09 \%)$. Generally, the three feed rations given to Mojosari duck in this study have good nutritional quality.

Table 1. Nutritional content of rations

\begin{tabular}{|c|c|c|c|c|c|c|}
\hline \multirow{2}{*}{ Rations } & \multicolumn{7}{|c|}{ Nutritional Content } \\
\cline { 2 - 7 } & EM (kcal) & PK (\%) & SK (\%) & LK (\%) & Ca (\%) & P (\%) \\
\hline Feed A & 2.951 & 18.97 & 6.83 & 4.85 & 6.09 & 0.63 \\
\hline Feed B & 3.100 & 17.25 & 5.8 & 5.32 & 4.87 & 0.82 \\
\hline Feed C & 3120 & 15.2 & 6.7 & 5.21 & 4.36 & 0.98 \\
\hline
\end{tabular}

Note: $\mathrm{EM}=$ metabolism energy, $\mathrm{PK}=$ crude protein, $\mathrm{SK}=$ crude fiber, $\mathrm{LK}=$ crude fat, $\mathrm{Ca}=$ Calcium, $\mathrm{P}=$ Phosphor

Source: Primary Data, IRIAP Laboratory, 2021

\subsection{Physical quality of eggs}

The results of the study in the form of the average physical quality of duck eggs feed A, B and $\mathrm{C}$ are presented in Table 2.

Table 2. Effect of local feed rations on physical quality, egg production, and feed costs.

\begin{tabular}{|l|c|c|c|}
\hline \multicolumn{1}{|c|}{ Parameter } & Feed A & Feed B & Feed C \\
\hline Egg weight $(\mathrm{g})$ & $73.95^{\mathrm{a}}$ & $71.13^{\mathrm{a}}$ & $61.58^{\mathrm{b}}$ \\
\hline Eggshell weight $(\mathrm{g})$ & $9.46^{\mathrm{a}}$ & $9.38^{\mathrm{a}}$ & $9.01^{\mathrm{a}}$ \\
\hline Shell thickness $(\mathrm{mm})$ & $0.20^{\mathrm{a}}$ & $0.21^{\mathrm{a}}$ & $0.56^{\mathrm{b}}$ \\
\hline Egg production $(\%)$ & 75 & 80 & 70 \\
\hline Egg yolk color & $11.2^{\mathrm{b}}$ & $9.3^{\mathrm{b}}$ & $4.8^{\mathrm{a}}$ \\
\hline
\end{tabular}

\subsubsection{Egg weight}

The effect of feed rations $\mathrm{A}$ and $\mathrm{B}$ provision was significantly different than that of feed $\mathrm{C}$ $(\mathrm{P}<0.05)$ on the weight of the eggs produced, but between feed rations $\mathrm{A}$ and $\mathrm{B}$ were not significantly different $(\mathrm{P}>0.05)$ (Table 2$)$. The highest egg weight was obtained by treatment A feed ration amounting to 73.95 grams. The weight of duck eggs that were raised semi-intensively ranged from 68.74 to 72.74 grams [14]. It means, this result was slightly higher than the range.

The weight of duck eggs can be affected by the nutritional content of the feed and the consumption of protein and amino acids. Variable egg weight can be caused by the varying 
content of crude protein in the feed. This study result showed duck given feed ration with higher crude protein content produce heavier egg (Table 2 and 3). This is in accordance with the opinion that the protein and fat content in feed can affect the weight of duck eggs [15].

Increasing or decreasing protein consumption can affect the weight of the eggs produced. An amount of feed according to the needs of ducks will produce an egg weight according to the standard [16]. Other factors that can affect egg weight are genetic factors, duck body weight, egg laying period, environment, egg and feed composition [17].

\subsubsection{Eggshell egg and thickness}

Statistical results showed that feeding rations $\mathrm{A}, \mathrm{B}$ and $\mathrm{C}$ had no significant effect on eggshell weight $(\mathrm{P}>0,05)$. The range of eggshell weight produced is between $9.01-9.46 \mathrm{~g}$. This value is greater than the weight of eggshell in other studies which only ranged from 7.05-7.4 g [18]. Eggshell weight in the Maju Jaya Livestock Group can be influenced by the calcium content in the feed and the size of the eggs produced [19].

The provision of feed ration $\mathrm{A}$ and $\mathrm{B}$ had a significant effect compared to feed ration $\mathrm{C}$ $(\mathrm{P}<0,05)$ on eggshell thickness. The $\mathrm{C}$ feed had thicker shells than the $\mathrm{A}$ and $\mathrm{B}$ rations, which was $0,56 \mathrm{~mm}$. The eggshell thickness of feed $\mathrm{C}$ was in the range of eggshell thickness in other studies that ranged from $0.5-0.6$ [20]. The eggshell thickness that is in the range between $0.5-0.52$ is quite good in the transportation process because eggs are not easily broken [18].

\subsubsection{Egg production}

The provision of feed rations $\mathrm{A}, \mathrm{B}$ and $\mathrm{C}$ did not significantly affect the production of duck eggs $(\mathrm{P}>0,05)$. The average production of duck eggs from the study was between $70-80 \%$. These results are not much different from the results of another research that the production of duck eggs reared with a semi-intensive system has an average of 73,06\% [21].

\subsubsection{Egg yolk color}

The statistical results showed that the yolk scores of ducks treated with feed A and B were significantly different than those of $\mathrm{C}$ feed $(\mathrm{P}<0,05)$, while the two treatments for feed $\mathrm{A}$ and $\mathrm{B}$ were not significantly different $(\mathrm{P}>0,05)$. This can be due to the nutrient content, especially crude protein in feed $\mathrm{C}$, which is lower than the crude protein content found in feed A and B.

The higher the yolk color score, the higher the vitamin A content in the yolk. The results obtained were higher than another research where ducks reared with a semiintensive system produced an average egg yolk color of 9,13 [21]. The duck raising system in the research location is a semi-intensive system. The ducks that are kept semi-intensively by being grazed in rice fields have a relatively high yolk color because ducks eat a lot of forage containing carotenoids [22].

\section{Conclusion}

The use of local feed-based rations can affect the physical quality of the eggs, but it does not affect the production of Mojosari duck eggs. The quality of Mojosari duck eggs in the Maju Jaya livestock group that is given local rations is classified as good quality based on egg weight, eggshell weight, and egg yolk color. Feed B is the best feed because it has the 
cheaper price and produces results that are not much different from feed A which has a higher protein content.

\section{References}

1. O. T. Toomer, E. Sanders, T. C. Vu, M. L. Livingston, B. Wall, R. D. Malheiros, L. V. Carvalho, K. A. Livingston, P. R. Ferket, K. E. Anderson, ACS Omega 5, 2, 1080-1085 (2020)

2. I. Ismoyowati, J. Sumarmono, in IOP Conf. Ser. Earth Environ. Sci 372 (2019)

3. Ismoyowati, Genetic diversity and conservation of local poultry, in Proceedings of the National Congress Livestock Technology and Agribusiness V to Support Food Security, Faculty of Animal Husbandry, Jenderal Soedirman University, 18 November 2017, Purwokerto, Indonesia (2017)

4. D. L. Yulianti, Muharlien, in IOP Conf. Ser. Earth Environ. Sci. 478 (2020)

5. M. Daud, M. A. Yaman, Zulfan, Asril, in IOP Conf. Ser. Earth Environ. Sci. 425 (2020)

6. DKP Riau Islands, Government Agencies Performance Report 2020 Department of Marine Affairs and Fisheries, Riau Islands Province (2020)

7. S. Biswas, R. Banerjee, D. Bhattacharyya, G. Patra, A. K. Das, S. K. Das, Worlds. Poult. Sci. J. 75, 4 (2019)

8. R. Eviyati, J. AGRIJATI 1, 1 (2005)

9. M. A. Umar, Genta Mulia 8, 90 (2020)

10. Y. T. Fitriza, F. T. Haryadi, S. P. Syahlani, Bul. Peternak. 36, 57 (2012)

11. M. Handayani, A. Setiadi, S. Gayatri, H. Setiyawan, J. Sos. Ekon. Peternak. 3, 1 (2007)

12. E. Setyo Budi, E. Yektiningsih, E. Priyanto, J. Agribus. Rural Dev. Res. 1, 1 (2015)

13. National Standardization Agency, SNI Bahan Pakan (BSN, Jakarta, 2006)

14. J. Abraham, R. Ravindran, Int. J. Poult. Sci. 8, 8 (2009)

15. M. Juliambarwati, A. Ratriyanto, A. Hanifa, Sains Peternak. 10, 1 (2017)

16. Ismoyowati, D. Purwantini, J. Pembang. Pedesaan 13, 1 (2013)

17. E. Tugiyanti, N. Iriyanti, J. Apl. Teknol. Pertan. 1, 44 (2012)

18. R. Simanjuntak, U. Santoso, T. Akbarillah, J. Sain Peternak. Indonesia 8, 65 (2013)

19. B. Aminuddin, L. . Mahfudz, R. Muryani, J. Sain Pe 14, 113 (2019)

20. M. Y. Bahtiar, D. L. Yulianti, A. T. N. Krisnaningsih, J. Sains Peternak. 5, 92 (2017)

21. E. Saelan, A. S. Nurdin, J. Ilmu Ternak 20, 102 (2020)

22. S. Tumanggor, B, G., Suci D, M, Suharti, Bul. Makanan Ternak 104, 21 (2017) 